ISSN: 2302-8556

E-Jurnal Akuntansi Universitas Udayana

Vol.26.3.Maret (2019): 2098 -2122

DOI: https://doi.org/10.24843/EJA.2019.v26.i03.p16

\title{
Pengaruh Audit Tenure dan Auditor Switching Pada Audit Delay Dengan Financial Distress Sebagai Variabel Pemoderasi
}

\author{
Luh Putu Yanti Pradnyaniti ${ }^{1}$ \\ I Made Sadha Suardikha ${ }^{2}$ \\ ${ }^{1,2}$ Fakultas Ekonomi dan Bisnis Universitas Udayana (Unud), Bali, Indonesia \\ e-mail: yantipradnyaniti@gmail.com
}

\begin{abstract}
ABSTRAK
Penelitian ini bertujuan untuk mendapatkan bukti empiris pengaruh audit tenure dan auditor switching pada audit delay dengan financial distress sebagai variabel pemoderasi. Metode penentuan sampel yang digunakan adalah purposive sampling. Jumlah sampel yang diperoleh sebanyak 23 perusahaan pertambangan di BEI tahun 2013-2017. Teknik analisis data yang digunakan yaitu uji Moderated Regression Analysis (MRA). Berdasarkan hasil penelitian, diketahui bahwa audit tenure berpengaruh negatif pada audit delay. Auditor switching tidak berpengaruh pada audit delay. Financial distress memperlemah pengaruh audit tenure pada audit delay. Financial distress tidak memoderasi pengaruh auditor switching pada audit delay. Implikasi teoretis penelitian ini adalah sebagai tambahan referensi penelitian selanjutnya mengenai penelitian yang berkaitan dengan audit delay dan teori sinyal serta teori kepatuhan.
\end{abstract}

Kata Kunci: Audit delay, audit tenure, auditor switching, financial distress

\begin{abstract}
This study aims to obtain empirical evidence of the effect of audit tenure and auditor switching on audit delay with financial distress as a moderating variable. The method of determining the sample used was purposive sampling. The number of samples obtained is 23 mining companies in BEI 2013-2017. The analysis techniques used is the Moderated Regression Analysis (MRA) test. Based on the results of the study, it is known that audit tenure has a negative effect on audit delay. Switching auditors have no effect on audit delay. Financial distress weakens the effect of audit tenure on audit delay. Financial distress is not moderate the effect of auditor switching on audit delay. The theoretical implications of this research are in addition to references to further research regarding research relating to audit delay and signal theory and compliance theory.
\end{abstract}

Keywords: Audit delay, audit tenure, auditor switching, financial distress

\section{PENDAHULUAN}

Laporan Keuangan adalah catatan informasi keuangan suatu perusahaan pada suatu

periode akuntansi yang dapat digunakan untuk menggambarkan kinerja perusahaan 
tersebut. Laporan keuangan harus transaparan dan informasi yang disajikan tepat waktu yang digunakan untuk mengambil keputusan. (Darmawan \& Widhiyani, 2017).

Peraturan Otoritas Jasa Keuangan Nomor 29/POJK.04/2016 mewajibkan untukperusahaan publik yang terdaftar di BEI untuk melaporkan laporan keuangan tahunan yang sudah di audit paling lambat bulan keempat (120 hari) setelah tahun buku berakhir. Peraturan tersebut ditetapkan untuk semua pihak yang memiliki kepentingan agar dapat mengetahui dan memiliki informasi terbaru mengenai kondisi perusahaan. Ketidaktepatan waktu pelaporan laporan keuangan yang dilakukan oleh perusahaan akan dikenakan sanksi, baik saksi dalam bentuk peringatan tertulis, sanksi dalam bentuk denda.

Peraturan OJK dan pemberian saksi tidak membuat perusahaan disiplin dalam pelaporan laporan keuangannya, di Indonesia masih ada perusahaan yang terlambat menyampaikan laporan keuangannya. Berdasarkan informasi yang diperoleh dari situs www.idx.co.idpada tahun 2013 tercatat 17 perusahaan belum menyampaikan laporan keuangan yang sudah di audit, tahun 2014 terdapat 52 perusahaan yang belum menyampaikan laporan keuangan yang sudah di audit, tahun 2015 terdapat 18 perusahaan yang belum menyampaikan laporan keuangan yang sudah di audit, kemudian pada tahun 2016 terdapat 17 perusahaan yang belum menyampaikan laporan keuangan yang sudah di audit dan pada tahun 2017 terdapat 20 perusahaan yang belum menyampaikan laporan keuangan yang sudah di audit. Penelitian yang dilakukan oleh Karami et al., (2017) menghasilkan rata-rata audit delay 77 hari, 
ISSN: 2302-8556

sedangkan penelitian yang dilakukan oleh Abbott etal., (2012) menghasilkan rata-rata audit delay 59 hari.

Oladipupo \& Izedomi (2013) menyatakan bahwa laporan keuangan yang disampaikan secara tepat waktu merupakan atribut penting yang diinginkan dari setiap informasi akuntansi yang baik. Bonsón-Ponteet al..(2008) menyatakan penggunalaporan keuangan memerlukan informasi yang tepat waktu serta dapat diandalkan untuk pengambilan keputusan. Ketepatan waktu pelaporan laporan keuangan tidak dapat dipisahkan dengan audit delay.

Ashton et al., (1987) menyatakan bahwa audit delay merupakan lamanya waktu penyelesaian audit dari tanggal penutupan tahun buku sampai tanggal penyelesaian laporan auditor independen. Lamanya pemeriksaan laporan keuangan oleh auditor disebabkan karena adanya perbedaan padangan dalam masalah akuntansi dan auditing antara manajemen klien dengan auditor (Dyer \& Mc. Hugh, 1975). Terdapat faktor-faktor yang dapat mempengaruhi audit delay seperti audit tenure dan auditor switching.

Audit tenure merupakan lamanya hubungan kerja antara perusahaan dengan akuntan publik atau KAP yang sama selama waktu tertentu. Hal ini telah diatur dalam PP No. 20 Tahun 2015 pasal 11 tentang Praktik Akuntan Publik, dijelaskan bahwa KAP tidak lagi dibatasi dalam melakukan audt suatu perusahaan tetapi pembatasan hanya berlaku bagi akuntan publik yaitu selama 5 tahun berturut-turut. Menurut Leeet al., (2009) semakin lama suatu perusahaan menjadi klien dari suatu KAP, maka semakin pendek audit delay. Hal ini karena auditor sudah memahami sistem 
akuntansi perusahaan, sehingga dapat menyelesaikan proses audit lebih cepat. Sebaliknya, apabila auditor melakukan perikatan audit dengan klien yang baru maka memerlukan waktu yang lebih lama. Dalam penelitian Permata Dewi \& Afri Yuyetta (2014) menyatakan audit tenure berpengaruh pada audit delay, namun dalam penelitian Praptika \& Rasmini (2016) menyatakan bahwa audit tenure tidak berpengaruh pada audit delay.

Auditor switching juga dapat menimbulkan audit delay. Menurut Ahmed \& Hossain (2010) menyatakan auditor switching adalah putusnya hubungan auditor yang lama dengan perusahaan kemudian digantikan oleh auditor yang baru. Auditor Switching dapat dilakukan secara wajib maupun secara sukarela. Apabilaauditor switching dilakukan secara sukarela, maka perhatian utama adalah pada sisi klien. Sebaliknya, jika auditor switching dilakukan secara wajib, maka perhatian utama beralih kepada auditor. Pada saat auditor switching dilakukan secara sukarela, terdapat dua kemungkinan yang akan terjadi ketika klien mengganti auditornya yaitu, auditor mengundurkan diri atau auditor diberhentikan oleh klien. Berbeda dengan auditor switching secara sukarela yang bisa terjadi karena perselisihan antara klien dengan auditor, pada auditor switching secara wajib yang terjadi karena ada peraturan yang membatasinya, seperti yang telah diatur pada Peraturan Pemerintah No. 20 Tahun 2015. Perusahaan yang melakukan auditor switching akan mengangkat auditor yang baru, sehingga membutuhkan waktu yang lama untuk auditor yang baru dalam mengenali karakteristik usaha klien dan sistem akuntansiperusahaan klien (Praptika \& Rasmini, 2016). Dalam penelitian Wiryakriyana \& Widhiyani (2017) 
ISSN: 2302-8556

E-Jurnal Akuntansi Universitas Udayana

Vol.26.3.Maret (2019): 2098 -2122

menyatakan bahwa auditor switching berpengaruh terhadap audit delay, namun dalam penelitian Tambunan (2014) auditor switching tidak berpengaruh padaaudit delay.

Berdasarkan beberapa penelitian terdahulu yang telah diuraikan pada latar belakang menunjukan hasil yang tidak konsisten mengenai pengaruh audit tenure dan auditor switching padaaudit delay, sehingga pengaruh variabel-variabel tersebut perlu diteliti kembali dengan menambahkan variabel financial distress sebagai pemoderasi. Financial distress menggambarkan kondisi dimana hasil operasi perusahaan tidak cukup untuk memenuhi kewajiban perusahaan. Menurut Schwartz \& Soo (1996) menyatakan bahwa perusahaan yang mengalami financial distress, cenderung menyampaikan laporan keuangan tidak tepat waktu dibandingkan perusahaan yang tidak sedang mengalami financial distress.Menurut Salehi \& Abedini (2009) kondisi perusahaan yang sedang mengalami financial distress dapat merugikan shareholder. Hal ini menggambarkan perusahaan telah mengalami kegagalan ekonomi (Gholizadeh et al, 2011). Kondisi financial distress pada perusahaan dapat meningkatkan resiko audit, khususnya resiko pengendalian dan resiko deteksi. Hal ini dapat mengakibatkan lamanya proses audit dan berdampak pada bertambahnya audit delay.

Penelitian ini melanjutkan dari penelitian terdahulu Wulandari \& Wiratmaja (2017) dengan mengganti variabel ukuran perusahaan klien dengan variabel auditor switching. Penelitian ini dilakukan pada perusahaan yang terdaftar di Bursa Efek Indonesia tahun 2013-2017, yaitu perusahaan pertambangan. Perusahaan ini dipilih 
karena sektor pertambangan mengalami peningkatan dari tahun ke tahun sebagai salah satu sektor yang berperan besar dalam pertumbuhan ekonomi.

Audit tenure merupakan jangka waktu penugasan audit antara pihak auditor (Kantor Akuntan Publik) dengan perusahaan yang diaudit secara terus menerus tanpa mengganti pihak akuntan publik yang lain. Untuk menjaga independensi auitor, pemerintah mengeluarkan PP No. 20 Tahun 2015 pasal 11 tentang praktik akuntan publik.

Berdasarkan teori sinyal, apabila laporan keuangan disampaikan tepat waktu, maka itu merupakan good news sehingga dapat meningkatkan harga saham perusahaan. Tenure yang panjang suatu KAP akan menambah pengetahuan KAP sehingga auditordapat memahami bisnis perusahaan dan dapat merencanakan program audit yang lebih baik. Semakin lama masa penugasan KAP dengan perusahaan akan meningkatkan efisiensi audit terhadap auditor sehingga dapat mempercepat proses audit.

Hal ini didukung oleh penelitian Ratnaningsih \& Dwirandra (2016) dan Roynaldo (2015) menyatakan bahwa audit tenure berpengaruh negatif terhadap audit report lag, karena saat auditor memiliki perikatan dengan waktu yang lebih lama dengan perusahaan klien, maka auditor sudah memahami mengenai karakteristik perusahaan, sehingga dapat mempersingkat audit delay.

$\mathrm{H}_{1}$ : Audit tenure berpengaruh negatif padaaudit delay

Auditor switching adalah putusnya hubungan dengan auditor yang lama dan menggantikannya dengan auditor yang baru(Tambunan,2014). Dalam teori sinyal 
ISSN: 2302-8556

menunjukan bahwa auditor switching merupakan berita yang tidak menguntungkan bagi investor dan perusahaan, karena dengan adanya auditor switching dapat menyebabkan terlambatnya pelaporan keuangan.

Hal ini didukung oleh penelitian Praptika \& Rasmini (2016) dan verawati andhika \& Wirakusuma (2016) mengemukakanauditor switching berpengaruh positif pada audit delay, karena perusahaan yang melakukan auditor switching akan menyebabkan auditor yang baru memerlukan waktu yang lebih lama untuk menyelesaikan proses auditnya. Berdasarkan telaah teori dan hasil penelitian terdahulu, maka dirumuskan hipotesis sebagai berikut:

\section{$\mathrm{H}_{2}$ : Auditor Switching berpengaruh positif pada audit delay}

Menurut Platt \& Platt (2002) financial distress merupakan tahap penurunan kondisi keuangan yang terjadi, sebelum terjadinya kebangkrutan. Baldwin \& Mason (1983) menyatakan bahwa suatu perusahaan yang mengalami financial distress apabila perusahaan tersebut tidak dapat memenuhi kewajiban finansialnya. Berdasarkan signalling theory apabila perusahaan sedang mengalamifinancial distress, maka itu merupakan sinyal buruk bagi investor. Schwartz \& Menon (1985)mengemukakan bahwa financial distress memiliki pengaruh signifikan pada perusahaan yang terancam bangkrut untuk berpindah KAP. Financial distress menyebabkan perusahaan berpotensi bangkrut yang mengindikasikan kemampuan keuangan perusahaan semakin berkurang untuk membayarkan fee audit yang dibebankan oleh akuntan publik maupun KAP nya, sehingga dapat menyebabkan putusnya hubungan kerja antara manajemen dengan pihak akuntan publik maupun 
dengan KAP. Semakin meningkatnya audit tenure maka pemahaman auditor atas karakteristik perusahaan dan sistem akuntansi perusahaan akan turut meningkat, sehingga dapat menyelesaikan proses audit lebih cepat. Sebaliknya apabila auditor melakukan perikatan audit dengan klien baru maka waktu penyelesaian audit akan lebih panjang.

Penelitian yang dilakukan oleh Sawitri dan Budiartha (2018) mengemukakan financial distress berpengaruh positif terhadap audit delay sedangkan penelitian yang dilakukan oleh Budiasih dan Saputri (2014) menyatakan financial distress tidak berpengaruh pada audit delay. Berdasarkan uraian tersebut, maka dapat dirumuskan hipotesis sebagai berikut:

$\mathrm{H}_{3}$ : Financial Distress memperlemah pengaruh audit tenure pada audit delay

Perusahaan yang menggalami financial distress lebih memilih untuk melakukan auditor switching dibandingkan perusahaan dengan kondisi keuangan yang sehat. Menurut Haskin \& Williams (1990) menyatakan bahwa financial distress merupakan salah satu faktor yang mempengaruhi keputusan klien untuk melakukan auditor switching. Penelitian yang dilakukan oleh Schwartz \& Menon (1985) menyatakan bahwa perusahaan akan melakukan auditor switching ketika perusahaan dalam kondisi financial distress.

Auditor switching merupakan sinyal buruk bagi pihak-pihak yang berkepentingan tentang kondisi keuangan perusahaan. Perusahaan yang sedang dalam kondisi financial distress akan melakukan auditor switching dengan mencari auditor dengan independensi yang tinggi, untuk meningkatkan kepercayaan diri perusahaan 
ISSN: 2302-8556

E-Jurnal Akuntansi Universitas Udayana

Vol.26.3.Maret (2019): 2098 -2122

dimata para pemegang saham dan kreditur. Jika suatu perusahaan mengalami auditor switching, akan membutuhkan waktu yang bagi auditor yang baru untuk memahami karakteristik bisnis klien dan sistem yang digunakan oleh perusahaan tersebut.

Penelitian yang dilakukan oleh Sawitri \& Budiartha (2018) menyatakan bahwa financial distress berpengaruh positif terhadap audit delay, sedangkan penelitian yang dilakukan oleh Budiasih dan Saputri (2014) menyatakan bahwa financial distress tidak berpengaruh pada audit delay. Berdasarkan telaah teori dan hasil-hasil penelitian terdahulu, maka dirumuskan hipotesis sebagai berikut:

$\mathrm{H}_{4}$ : Financial Distress memperkuat pengaruh auditor switching pada audit delay.

\section{METODE PENELITIAN}

Penelitian dilakukan pada perusahaan pertambangan yang terdaftar di Bursa Efek Indonesia tahun 2013-2017 dengan mengakses situs resmi Bursa Efek Indonesia yaitu www.idx.co.id. Objek penelitian ini adalah audit delay yang dijelaskan oleh audit tenure, auditor switching, interaksi antara audit tenure dengan financial distress, dan interaksi antara auditor switching dengan financial distress. Audit tenure di ukur dengan menggunakan angka 1,2,3,4,5 yang disesuaikan dengan lamanya hubungan auditor dengan klien. Auditor switching diukur dengan menggunakan variabel dummy, perusahaan yang melakukan auditor switching diberi kode 1 dan tidak melakukan auditor switching diberi kode 1. Financial distress di ukur menggunakan rasio DAR (debt to assets ratio). Semakin tinggi rasio DAR maka semakin tinggi 
resiko keuangan perusahaan. Adapun rumus DAR (Debt to Assets Ratio) adalah sebagai berikut:

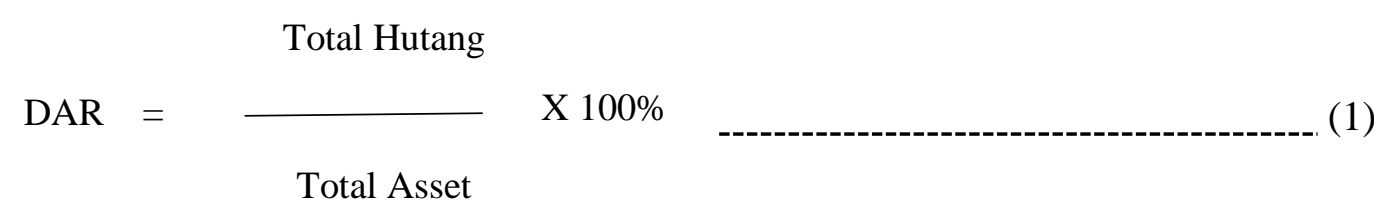

Populasi penelitian ini adalah seluruh perusahaan pertambangan yang terdaftar di BEI tahun 2013-2017. Jumlah perusahaan pertambangan yang terdaftar di BEI berjumlah 46 perusahaan. Sampel dalam penelitian ditentukan menggunakan metode nonprobability sampling dengan teknik purposive sampling, yaitu penentuan sampel dengan menggunakan kriteria tertentu. Kriteria sampel ditunjukan pada tabel 1.

Tabel 1.

\section{Ringkasan Perolehan Sampel}

\begin{tabular}{clc}
\hline No & \multicolumn{1}{c}{ Kriteria } & Jumlah Sampel \\
\hline 1. & Jumlah perusahaan pertambangan yang terdaftar di & 46 \\
& BEI pada tahun 2014-2017. & (13) \\
2. & Perusahaan pertambangan yang tidak & \\
& mempublikasikan laporan keuangan auditan secara & \\
& lengkap dan berturut-turut selama periode 2014- & 33 \\
& 2017. & 165 \\
Jumlah perusahaan sampel &
\end{tabular}
Sumber: Bursa Efek Indonesia, 2018

Teknik analisis data yang digunakan adalah uji MRA (Moderated Regression Analysis), data yang telah dikumpulkan dalam penelitian diolah dengan program SPSS 22. MRA (Moderated Regression Analysis ) merupakan aplikasi khusus berganda linear dimana dalam persamaan regresinya mengatur unsur interaksi. Model persamaan MRA yang dibentuk dalam penelitian ini adalah:

$$
Y=\alpha_{1}+\beta_{1} X_{1}+\beta_{2} X_{2}+\beta_{3} X_{3}+\beta_{4}\left(X_{1} X_{3}\right)+\beta_{5}\left(X_{2} X_{3}\right)+e
$$


Keterangan:

$\mathrm{Y}=$ Audit Delay

$\beta_{1}=$ koefisien audit tenure

$\beta_{2}=$ koefisien auditor switching

$\beta_{3}=$ koefisien financial distress

$\beta_{4}=$ koefisien audit tenure dan financial distress

$\beta_{5}=$ koefisien auditor switching dan financial distress

$\mathrm{X}_{1}=$ Audit Tenure

$\mathrm{X}_{2}=$ Auditor Switching

$\mathrm{X}_{3}=$ financial distress

$\mathrm{X}_{1} \mathrm{X}_{3}=$ interaksi antara audit tenure dengan financial distress

$\mathrm{X}_{2} \mathrm{X}_{3}=$ interaksi antara auditor switching dengan financial distress

$\alpha=$ Konstanta

$\mathrm{e}=$ error

\section{HASIL DAN PEMBAHASAN}

Statistik deskriptif berfungsi untuk mengalisis data dengan menggambarkan sampel data yang dikumpulkan tanpa mengeneralisasi. .Hasil uji statistik deskriptif penelitian dapat dilihat pada tabel 2 sebagai berikut:

Tabel 2.

Hasil Statistik Deskriptif

\begin{tabular}{lccccc}
\hline & $\mathrm{N}$ & Minimum & Maximum & Mean & Std. Deviation \\
\hline $\mathrm{Y} 1$ & 115 & 18,00 & 206,00 & 78,6435 & 25,62455 \\
$\mathrm{X} 1$ & 115 & 1,00 & 5,00 & 2,5826 & 1,42030 \\
$\mathrm{X} 2$ & 115 &, 00 & 1,00 &, 4087 &, 49374 \\
$\mathrm{X} 3$ & 115 &, 04 & 1,08 &, 5074 &, 22083 \\
$\mathrm{X} 1 \_X 3$ & 115 &, 07 & 5,40 & 1,3213 &, 97614 \\
$\mathrm{X} 2 \_X 3$ & 115 &, 00 & 1,08 &, 2187 &, 30339 \\
Valid N (listwise) & 115 & & & & \\
\hline
\end{tabular}

Sumber: Data diolah, 2018

Varibel audit delay memiliki nilai minimum sebesar 18,00, nilai maksimum 206,00, nilai rata-rata sebesar 78,6435 dan standar deviasi sebesar 25,65455. Nilai minimum pada PT. Central Omega Resources Tbk. Nilai maksimum pada PT. 
Apexindo Pratama Duta Tbk. Nilai rata-rata 78, 6435 berarti rata-rata waktu yang diperlukan perusahaan untuk mempublikasikan laporan keuangan selama 78 hari. Nilai standar deviasi variabel audit delay sebesar 25,65455 hari.

Variabel audit tenure memiliki nilai minimum sebesar 1,00, nilai maksimum sebesar 5,00, nilai rata-rata sebesar 2,5826 dan nilai standar deviasi sebesar 1,42030. Nilai minimum sebesar 1,00 berarti audit tenure dengan tenure terpendek adalah 1 tahun, nilai maksimum sebesar 5,00 berarti audit tenure dengan tenure terlama yaitu 5 tahun. Nilai rata-rata audit tenure adalah 2,5826 tahun. Nilai standar audit tenure adalah sebesar 1,42030 tahun.

Variabel auditor switching memiliki nilai minimum sebesar 0,00, nilai maksimum sebesar 1,00, nilai rata-rata sebesar 0,4087 dan nilai standar deviasi sebesar 0,49374. Nilai minimum sebesar 0,00 menggambarkan bahwa perusahaan tersebut tidak melakukan pergantian auditor, nilai maksimum sebesar 1,00 menggambarkan bahwa perusahaan tersebut melakukan pergantian auditor. Nilai ratarata sebesar 0,40 berrati sebesar $40 \%$ perusahaan melakukan auditor switching dan sisanya sebesar $60 \%$ persen perusahaan tidak melakukanauditor switching. Nilai standar deviasi auditor switching adalah sebesar 0,49374.

Variabel financial distress memiliki nilai minimum sebesar 0,04, nilai maksimum sebesar 1,08, nilai rata-rata sebesar 0,5074 dan nilai standar deviasi sebesar 0,22083. Dalam penelitian ini financial distress diproksikan dengan DAR (debt to asset ratio). Nilai minimum sebesar 0,04 pada PT. Central Omega Resources Tbk (DKFT). Nilai maksimum sebesar 1,08 pada PT. Apexindo Pratama Duta Tbk. 
Nilai rata-rata sebesar 0,5074 menggambarkan bahwa rata-rata kemampuan perusahaan pertambangan yang terdaftar di BEI tahun 2013-2017 untuk melunasi kewajibannya sebesar 0,5074. Nilai standar deviasi financial distress adalah sebesar 0,22083 .

Uji asumsi klasik dilakukan untuk memastikan bahwa sampel yang diteliti terbebas dari gangguan normalitas, autokorelasi dan heteroskedastisitas. Uji normalitas digunakan untuk mengetahui apakah model regresi dan variabel pengganggu berdistribusi normal. Hasil uji normalitas dapat disajikan dalam tabel 3.

\section{Tabel 3.}

Hasil Uji Normalitas

\begin{tabular}{ccc}
\hline & & $\begin{array}{c}\text { Unstandardized } \\
\text { Residual }\end{array}$ \\
\hline \multirow{2}{*}{ Normal Parameters $^{\mathrm{a}, \mathrm{b}}$} & Mean & 115 \\
& Std. Deviation &, 0000000 \\
Most Extreme Differences & Absolute &, 32093958 \\
& Positive &, 059 \\
& Negative &,- 036 \\
Test Statistic & &, 059 \\
Asymp. Sig. (2-tailed) &, $200^{\mathrm{d}}$ \\
\hline
\end{tabular}

Sumber: Data diolah, 2018

Hasil uji normalitas menunjukan nilai Asymp. Sig (2-tailed) sebesar 0,200 lebih besar dari 0,05, sehingga dapat disimpulkan bahwa data yang diuji berdistribusi normal. Uji Autokorelasi berujuan untuk mengetahui apakah model regresi terdapat korelasi antara kesalahan pengganggu pada periode t dengan kesalahan pengganggu pada periode t-1 atau penelitian sebelumnya. Hasil uji autokorelasi dalam penelitian ini adalah $\mathrm{dU}<\mathrm{DW}<4$-dU atau $1,731<1,951<2,269$, maka tidak terjadi autokorelasi. 
Uji Heteroskedastisitas bertujuan untuk mengetahui apakah dalam model regresi linear terjadi ketidaksamaan variance dari residual satu ke pengamatan lainnya, penelitian ini menggunakan Uji glejser. Hasil uji heteroskedastisitas disajikan dalam tabel 4.

\section{Tabel 4.}

\section{Hasil Uji Heteroskedastisitas}

\begin{tabular}{lccccc}
\hline \multicolumn{7}{c}{ Unstandardized Coefficients } & $\begin{array}{c}\text { Standardized } \\
\text { Coefficients }\end{array}$ & & \\
Model & $\mathrm{B}$ & Std. Error & Beta & $\mathrm{t}$ & Sig. \\
\hline (Constant) &, 841 &, 075 & & 11,268 &, 000 \\
X1 &,- 003 &, 100 &,- 004 &,- 033 &, 974 \\
X2 &,- 150 &, 306 &,- 047 &,- 489 &, 626 \\
X3 &, 036 &, 047 &, 072 &, 758 &, 450 \\
X1_X3 &, 065 &, 047 &, 148 & 1,399 &, 165 \\
X2_X3 &, 150 &, 089 &, 158 & 1,684 &, 095 \\
\hline
\end{tabular}

Sumber: Data diolah, 2018

Hasil uji heteroskedastisitas menunjukan nilai signifikansi seluaruh variabel bebas lebih besar dari 0,05 . Hal ini berarti model regresi penelitian bebas dari gejala heteroskedastisitas.Uji MRA dilakukan untuk mengetahui pengaruh audit tenure dan auditor switching pada audit delay dengan financial distress sebagai variabel pemoderasi. Hasil uji MRA disajikan dalam tabel 5 sebagai berikut:

\section{Tabel 5.}

Hasil Uji Moderated Regression Analysis (MRA)

\begin{tabular}{lccccc}
\hline \multicolumn{7}{c}{ Unstandardized Coefficients } & $\begin{array}{c}\text { Standardized } \\
\text { Coefficients }\end{array}$ & & \\
Model & $\mathrm{B}$ & Std. Error & Beta & $\mathrm{t}$ & Sig. \\
\hline (Constant) & 73,279 & 9,877 & & 7,419 &, 000 \\
X1 & $-8,859$ & 3,516 &,- 491 & $-2,520$ &, 013 \\
X2 & $-2,740$ & 10,170 &,- 053 &,- 269 &, 788 \\
X3 & $-5,181$ & 18,332 &,- 045 &,- 283 &, 778 \\
X1_X3 & 19,967 & 6,333 &, 761 & 3,153 &, 002 \\
X2_X3 & 25,655 & 18,027 &, 304 & 1,423 &, 158 \\
Adj $\mathrm{R}^{2}=0,369$ & & & & & \\
$\mathrm{~F}_{\text {hitung }}=14,324$ & & & & & \\
Sig. F & & & & & \\
Sumber: $:$ Datang $=0,000$ & & & & &
\end{tabular}


ISSN: 2302-8556

E-Jurnal Akuntansi Universitas Udayana

Vol.26.3.Maret (2019): 2098 -2122

Berdasarkan Tabel 5, maka diperoleh persamaan regresi sebagai berikut:

$Y=73,279-8,859 X_{1}-2,740 X_{2}-5,181 X_{3}+19,967 X_{1} X_{3}+25,655 X_{2} X_{3}+e$

Nilai konstantabernilai positif sebesar 73,279 berarti apabila audit tenure, auditor switching dan financial distress sama dengan nol, maka audit delay sebesar 73,279 .

Variabel audit tenure menunjukan koefisien sebesar -8,859 berarti jika nilai audit tenure meningkat sebesar satu satuan, maka audit delay akan menurun sebesar 8,859 satuan, dengan asumsi variabel independen lainnya konstan.

Varibel auditor switching menunjukan koefisien sebesar -2,740 berarti jika nilai auditor switching meningkat sebesar satu satuan, maka audit delay akan menurun sebesar 2,740 satuan, dengan asumsi variabel indepeden lainnya konstan.

Variabel financial distress menunjukan koefisien sebesar -5,181 berarti jika financial distress yang di proksikan dengan debt to to assets ratio meningkat sebesar satu satuan, maka audit delay menurun sebesar 5,181 satuan, dengan asumsi variabel independen lainnya konstan.

Nilai koefisiensi interaksi antara audit tenure dengan financial distress sebesar 19,967 berarti apabila interaksi antara audit tenure dengan financial distress meningkat sebesar satu satuan, maka audit delay akan meningkat sebesar 19,967 satuan, dengan asumsi variabel independen lainnya konstan.

Nilai koefisiensi interaksi antara auditor switching dengan financial distress sebesar 25,655 berarti apabila interaksi antara auditor switching dengan financial 
distress meningkat sebesar satu satuan, maka audit delay akan meningkat sebesar 25,655 satuan, dengan asumsi variabel independen lainnya konstan.

Tabel 5 menunjukan besar $F_{\text {hitung }}$ yang diperoleh sebesar 14,324 dengan signifikansi 0,000. Nilai signifikansi ini lebih kecil dari $0,05(\mathrm{~F}<\alpha)$ yang berarti bahwa model penelitian ini dinyatakan layak untuk digunakan sebagai model regresi. hasil ini memberikan makna bahwa seluruh variabel independen yaitu audit tenure, auditor switching, financial distress, interaksi antara audit tenure dengan financial distress dan interaksi antara auditor switching dengan financial distress mampu memprediksi atau menjelaskan fenomena audit delay pada perusahaan pertambangan yang terdaftar di BEI periode 2013-2017.

Tabel 5 menunjukan nilai $A d j \mathrm{R}^{2}$ adalah sebesar 0,369. Hal ini berarti bahwa sebesar 36,90 \% dari audit delay dipengaruhi oleh audit tenure, auditor switching dan financial distress, sedangkan 63,10 \%sisanya dijelaskan oleh variabel lain yang tidak diuji pada penelitian ini.

Variabel audit tenure memiliki nilai signifikasi t sebesar 0,013 lebih kecil dari $0,05(\operatorname{Sig}<\alpha)$ dan memilikinilai t hitung sebesar-2,520, sehingga $\mathrm{H}_{0}$ ditolak dan $\mathrm{H}_{1}$ diterima. Hal ini menunjukan bahwa audit tenure berpengaruh negatif pada audit delay.

Variabel auditor switching memiliki nilai signifikansi t sebesar 0,788 yang lebih besar dari 0,05 $(\mathrm{Sig}>\alpha)$ dan nilai t hitung sebesar $-0,269$, sehingga $\mathrm{H}_{0}$ diterima dan $\mathrm{H}_{2}$ ditolak. Hal ini menunjukan bahwa auditor switching tidak berpengaruh pada audit delay. 
ISSN: 2302-8556

Variabel interaksi antara audit tenure dengan financial distress memiliki nilai signifikansi t sebesar 0,002 lebih kecil dari 0,05 (Sig $<\alpha)$ dan nilai hitung sebesar 3,153, sehingga $\mathrm{H}_{0}$ ditolak dan $\mathrm{H}_{3}$ diterima. Hal ini menunjukan bahwa financial distress memoderasi pengaruh audit tenure pada audit delay.

Variabel interaksi antara auditor switching dengan financial distress memiliki nilai signifkansi t sebesar 0,158 lebih besar dari 0,05 ( $\mathrm{Sig}>\alpha)$ dan nilai t hitung sebesar 1,423, sehingga $\mathrm{H}_{0}$ diterima dan $\mathrm{H}_{4}$ ditolak. Hal ini berarti bahwa financial distress tidak memoderasi pengaruh auditor switching pada audit delay.

$\mathrm{H}_{1}$ menyatakan bahwa audit tenure berpengaruh negatif pada audit delay. Hasil penelitian menunjukan bahwa $\beta_{1}=-8,859$ dengan nilai tingkat signifikansi sebesar 0,013 yang lebih kecil dari taraf nyata sebesar 0,05. Dengan demikian dapat diartikan bahwa audit tenure berpengaruh negatif pada audit delay, maka $\mathrm{H}_{1}$ dalam penelitian ini diterima.

Hasil penelitian ini sejalan dengan hasil penelitian Ratnaningsih dan Dwirandra (2016), Permata Dewi dan Afri Yuyetta (2014) serta Annisa dan Unggul (2018) yaitu audit tenure berpengaruh negatif pada audit delay. Berdasarkan teori sinyal, apabila laporan keuangan disampaikan tepat waktu, maka itu merupakan good news sehingga dapat meningkatkan harga saham perusahaan. Semakin lama auditor melakukan perikatan audit dengan perusahaan klien, maka auditor akan mengetahui tentang karakteristik klien dan sistem operasional bisnis kliennya sehingga dapat menyelesaikan proses audit untuk laporan keuangan dengan lebih cepat. 
$\mathrm{H}_{2}$ menyatakan bahwa auditor switching berpengaruh positif pada audit delay. Hasil penelitian menunjukan bahwa bahwa $\beta_{2}=-2,740$ dengan nilai tingkat signifikansi sebesar 0,788 yang lebih besar dari taraf nyata yaitu 0,05 . Dengan demikian, menunjukan bahwa auditor switching tidak berpengaruh pada audit delay, maka $\mathrm{H}_{2}$ dalam penelitian ini ditolak.

Hal ini sejalan dengan penelitian Sonya Maretha Syah (2017), Tambunan (2014) serta Megayanti dan Budiartha (2016) yaitu auditor switching tidak berpengaruh pada audit delay. Lamanya proses audit tidak dipengaruhi oleh auditor switching, hal ini disebabkan karena auditor switching dapat dilakukan jauh sebelum tahun tutup buku berakhir. Oleh karena itu, auditor switching tidak mempengaruhi audit delay karena auditor switching tidak akan mengganggu lamanya proses audit sebab auditor switching dilakukan jauh sebelum tanggal tahun buku berakhir.

$\mathrm{H}_{3}$ menyatakan bahwa financial distress memperlemah pengaruh audit tenure pada audit delay. Hasil penelitian menunjukan bahwa $\beta_{1}=19,967$ dengan nilai tingkat signifikansi sebesar 0,002 yang nilainya lebih kecil dari taraf nyata yaitu sebesar 0,05. Dengan demikian, menunjukan bahwa financial distress memperlemah pengaruh audit tenure pada audit delay, maka $\mathrm{H}_{3}$ diterima. Interaksi antara variabel audit tenure dengan financial distress disebut pure moderator (moderasi murni) yakni dapat dilihat dari hasil $\beta_{3}$ non significant dan $\beta_{4}$ significant. Pure moderator (moderasi murni) merupakan variabel yang hanya berperan sebagai pemoderasi hubungan antara variabel bebas dengan variabel terikat. 
ISSN: 2302-8556

Hubungan antara audit tenure dengan audit delay yang awalnya negatif setelah ditambahkan variabel financial distress sebagai moderasi menjadi melemah. Hal ini disebabkan karena terjadinya financial distress pada suatu perusahaan akan menyebabkan auditor menafsirkan risiko audit yang lebih tinggi. Penetapan risiko audit yang tinggi pada perusahaan yang mengalami financial distress disebabkan karena perusahaan cenderung untuk melakukan window dressing demi menjaga reputasi perusahaan dimata stakeholder (Wulandari dan Wiratmaja, 2017). Perusahaan yang mengalami financial distress akan menunjukan sinyal bahwa perusahaan sedang dalam keadaan yang sulit, sehingga perusahaan akan menunda publikasi dari laporan keuangan dan cenderung mengulur waktu dalam proses audit.

$\mathrm{H}_{4}$ menyatakan bahwa financial distress memperkuat pengaruh auditor switching pada audit delay. Hasil penelitian menunjukan bahwa $\beta_{4}=25,655$ dengan nilai tingkat signifikansi sebesar 0,158 yang lebih besar dari taraf nyata yaitu sebesar 0,05. Dengan demikian, menunjukan bahwafinancial distress tidak memoderasi pengaruh auditor switching pada audit delay, sehingga $\mathrm{H}_{4}$ ditolak. Interaksi antara variabel auditor switching dengan financial distress disebut homologiser moderator (moderasi potensial), yakni dapat dilihat dari nilai $\beta_{3}$ non significant dan $\beta_{5}$ non significant. Homologiser moderator berarti variabel tersebut potensial menjadi variabel moderasi.

Financial distress tidak memoderasi auditor switching pada audit delay. Hal ini terjadi karena perusahaan klien yang sedang mengalami financial distress merasa perlu untuk mendapatkan saran-saran perbaikan dari auditor yang melakukan audit 
pada perusahaan agar dapat keluar dari kondisi financial distress, sehingga tidak mengindikasikan bahwa perusahaan pasti akan tidak tepat waktu dalam mempublikasikan laporan keuanganya. Apabila perusahaan melakukan auditor switching saat keadaan perusahaan mengalami kesulitan keuangan maka akan semakin menyulitkan perusahaan, karena biaya untuk membayar auditor yang baru relatif tinggi.

Penelitian ini menghasilkan bukti empiris bahwa audit tenure berpengaruh negatif pada audit delay. Hal ini dapat dikaitkan dengan teori sinyal, apabila laporan keuangan disampaikan tepat waktu, maka itu merupakan good news dan dapat meningkatnya harga saham perusahaan, sehingga investor tertarik untuk berinvestasi di perusahaan. Semakin lama perikatan kerja auditor dengan kliennya maka akan membuat auditor memiliki pengetahuan mengenai karakteristik dari kliennya, sehingga akan memudahkan auditor untuk merancang program audit yang efektif dan dapat mengurangi audit delay.

Penelitian ini juga menghasilkan bukti empiris mengenai auditor switching tidak berpengaruh pada audit delay. Hasil ini tidak mendukung teori sinyal yang menyatakan bahwa auditor switching merupakan berita yang tidak menguntungkan bagi investor dan perusahaan, karena dengan adanya auditor switching dapat menyebabkan terlambatnya pelaporan keuangan. Keputusan untuk menerima klien dibuat dalam waktu enam sampai sembilan bulan sebelum tahun fiskal klien berakhir, setelah itu auditor akan melakukan perencanaan audit, perencanaan audit dilakukan tiga sampai enam bulan sebelum tahun fiskal klien berakhir sehingga auditor 
ISSN: 2302-8556

E-Jurnal Akuntansi Universitas Udayana

Vol.26.3.Maret (2019): 2098 -2122

switching tidak akan mengganggu proses audit dan bahwa dapat melakukan pekerjaan audit lebih baik karena sudah menjadwalkan pekerjaan mereka sehingga mereka dapat menyelesaikan audit secara tepat waktu.

Penelitian ini juga menghasilkan bukti empiris mengenai financial distress memperlemah pengaruh audit tenure pada audit delay. Hal ini mendukung signalling theory yang menyatakan perusahaan sedang mengalami kesulitan keuangan, maka itu merupakan sinyal buruk bagi investor, karena perusahaan akan kesulitan dalam melunasi kewajibannya.

Penelitian ini juga menghasilkan bukti empiris mengenai financial distress tidak mampu memoderai pengaruh auditor switching pada audit delay. Hal ini tidak mendukung teori sinyal yang menyatakan perusahaan yang sedang mengalami financial distress cenderung akan mengganti auditornya, sehingga menyebabkan terlambatnya penyampaian laporan keuangan dan merupakan bad news bagi perusahaan dan investor, karena ketika perusahaan mengalami financial distress , perusahaan meminta saran dari auditor yang melakukan audit agar dapat keluar dari kondisi financial distress, sehingga tidak mengindikasikan perusahaan pasti tidak akan terlambat menyampaikan laporan keuangannya

Implikasi praktis dari penelitian ini, yaitu sebagai penelitian ini diharapkan dapat menjadi referensi bagi auditor dalam mengoptimalkan kinerja auditnya, khususnya untuk peningkatan efisiensi dan efektivitas dalam hal ketepatwaktuan dalam mempublikasikan laporan keuangan. Pemerintah yaitu Otoritas Jasa Keuangan lebih memperketat sanksi yang diberikan kepada perusahaan yang terlambat 
melaporkan keuangannya, agar dapat memberikan efek jera kepada perusahaan yang terlambat dalam melaporkan laporan keuangannya, karena masih ada perusahaan yang melebihi batas.

\section{SIMPULAN}

Audit tenure berpengaruh negatif pada audit delay, hal ini disebabkan karena semakin lama masa perikatan audit dengan perusahaan maka akan semakin cepat proses audit sehingga pelaporan lapiran keuangan akan tepat waktu dan dapat mengurangi audit delay.Auditor switching tidak berpengaruh pada audit delay. Hal ini berarti, auditor switching dalam suatu perusahaan dapat dilakukan jauh sebelum tanggal berakhirnya tahun buku, sehingga tidak akan mengganggu proses audit. Financial distress memperlemah pengaruh audit tenure pada audit delay, karena auditor menafsirkan risiko audit yang tinggi sehingga menyebabkan lamanya penyelesaian proses audit dan memperpanjang audit delay. Financial distress tidak memoderasi pengaruh auditor switching pada audit delay, karena perusahaan klien yang sedang mengalami financial distress merasa perlu untuk mendapatkan saran-saran perbaikan dari auditor yang melakukan audit pada perusahaan agar dapat keluar dari kondisi financial distress, sehingga tidak mengindikasikan bahwa perusahaan pasti akan tidak tepat waktu dalam mempublikasikan laporan keuanganya.

Saran yang diberikan untuk peneliti selanjurnya adalah peneliti selanjutnya disarankan menambah beberapa variabel lain seperti variabel reputasi auditor, tingkat spesialisasi auditor dan ukuran perusahaan yang diduga mampu mampu 
ISSN: 2302-8556

E-Jurnal Akuntansi Universitas Udayana

Vol.26.3.Maret (2019): 2098 -2122

mempengaruhi audit delay serta memperluas sampel penelitian ke sektor perusahaan lain, serta saran untuk Otoritas Jasa Keuangan untuk lebih mempertegas sanksi yang diberikan kepada para perusahaan yang terlambat menyampaikan laporan keuangannya.

\section{REFERENSI}

Abbott, L. J., Parker, S., \& Peters, G. F. (2012). Internal audit assistance and external audit timeliness. Auditing, 31(4), 3-20. https://doi.org/10.2308/ajpt-10296

Ahmed, A. A. A., \& Hossain, M. S. (2010). Audit Report Lag: A Study of the Bangladeshi Listed Companies. ASA University Review, 4(2).

Annisa, D., \& Unggul, U. E. (2018). Pengaruh Ukuran Perusahaan , Jenis Opini Auditor, Ukuran Kap dan Audit Tenure terhadap Audit Delay. Jurnal Akuntansi Berkelanjutan Indonesia, 1(1), 108-121.

Ashton, R. H., Jhon, J. W., \& Robert, K. E. (1987). An Empirical Analysis of Audit Delay. Journal of Accounting Research, 25(2), 275-292.

Baldwin, C. , \& Mason, S. (1983). The Resolution of Claims in Financial Distress: the case of Massey Ferguson. Journal of Finance, 38(2), 505-516.

Bonsón-Ponte, E. E.-R., \& Borrero-Domínguez, C. (2008). Empirical Analysis of Delay in the Signing of Audit Reports in Spain. International Journal of Auditing, 12, 129-140.

Budiasih, I. G. A. N., \& Saputri, P. D. A. (2014). Corporate Governance dan Financial Distress pada Kecepatan Publikasi Laporan Keuangan. Kinerja, 18(2), $157-167$.

Darmawan, Y., \& Widhiyani, S. (2017). Pengaruh Ukuran Perusahaan, Kompleksitas Operasi Perusahaan dan Komite Audit pada Audit Delay. E-Jurnal Akuntansi Universitas Udayana, 21(1), 254-282.

Dyer, J. C., \& Mc. Hugh, A. J. (1975). The Timeliness of The Australian Annual Report. Journal of Accounting Research, 13(2), 204-219. 
Gholizadeh, M. H., Mohammad, M., Bahmani, A., \& Dizaji, B. S. (2011). Corporate Financial Distress Prediction Using Artificial NeuralNetworks and Using Microlevel Financial Indicators. Interdisciplinary Journal of Contemporary Research in Business, 3(5).

Haskin, M. E., \& Williams, D. D. (1990). A Contingent Model of Intra-Big Eight Auditor Changes. Auditing: A Journal of Practice and Theory, 9(3), 55-74.

Karami, G., Karimiyan, T., \& Salati, S. (2017). Auditor Tenure , Auditor Industry Expertise , and Audit Report Lag: Evidences of Iran, 10. https://doi.org/10.22059/ijms.2017.219348.672346

Lee, H.-Y., Mande, V., \& M, S. (2009). Do Lengthy Auditor Tenure and The Provision of Non-audit Services by The External Auditor Reduce Audit Report Lags? International Journal of Auditing, 13(2), 87-104.

Megayanti, P., \& Budiartha, I. K. (2016). Pengaruh Pergantian Auditor, Ukuran Perusahaan, Laba Rugi Dan Jenis Perusahaan Pada Audit Report Lag. E-Jurnal Akuntansi Universitas Udayana, 14(2), 1481-1509. https://doi.org/10.1128/AEM.02227-09

Oladipupo, A., \& Izedomi, F. (2013). Relative Contributions of Audit and Management Delays in Corporate Financial Reporting: Empirical Evidence from Nigeria. International Journal of Business and Social Science, 4(10), 199-204.

Permata Dewi, S. G., \& Afri Yuyetta, E. N. (2014). Pengaruh Kualitas Audit dan Tenure Audit Terhadap Audit Report Lag (ARL) Dengan Spesialisasi Auditor Industri Sebagai Variabel Moderasi (Studi Empiris pada Perusahaaan Manufaktur yang Listing di BEI Tahun 2010-2012). Diponegoro Journal of Accounting, 3, 24.

Platt, H. D., \& Platt, M. B. (2002). Predicting corporate financial distress: Reflections on choice-based sample bias. Journal of Economics and Finance, 26(2), 184199. https://doi.org/10.1007/BF02755985

Praptika, P. Y. H., \& Rasmini, N. K. (2016). Pengaruh Audit Tenure, Pergantian Auditor Dan Financial Distress Pada Audit Delay Pada Perusahaan Consumer Goods. E-Jurnal Akuntansi Universitas Udayana, ISSN: 2302-8556, 15(3), 2052-2081.

Ratnaningsih, ni made dwita, \& Dwirandra, A. A. N. . (2016). Spesialisasi Auditor Sebagai Variabel Pemoderasi Pengaruh Audit Tenure Dan Pergantian Auditor Pada Audit Delay. E-Jurnal Akuntansi Universitas Udayana, 16, 18-44. 
ISSN: 2302-8556

E-Jurnal Akuntansi Universitas Udayana

Vol.26.3.Maret (2019): 2098 -2122

Roynaldo, F. R. N. (2015). Pengaruh Audit Tenure dan Afiliasi KAP Terhadap Audit Report Lag dengan Spesialisasi Industri Auditor sebagai Variabel Pemoderasi (Studi Empiris pada Perusahaan yang Terdaftar di BEI Periode Tahun 20142015). E-Journal Uajy, 1-15. Retrieved from http://ejournal.uajy.ac.id/id/eprint/11968

Salehi, M., \& Abedini, B. (2009). Financial Distress Prediction in Emerging Market: Empirical Evidences from Iran. Business Intelligence Journal, 2(2), 398-409.

Sawitri, dwi candra, \& Budiartha, I. ketut. (2018). Pengaruh Audit Tenure dan Financial Distress pada Audit Delay dengan Spesialisasi Auditor Sebagai Variabel Pemoderasi. E-Jurnal Akuntansi Universitas Udayana, 22.3, 19651991.

Schwartz, K. ., \& Menon, K. (1985). Auditor Switches by Failing Firms. The Accounting Review, 60(2), 248-261.

Schwartz, K. B., \& Soo, B. S. (1996). Evidence of Regulatory Non-complience with SEC Disclosure Rules on Auditor Changes. The Accounting Review 4 (October), 555-572.

Sonya Maretha Syah, E. (2017). Pengaruh Solvabilitas, Kepemilikan Publik, Auditor Switching dan Perusahaan Holding terhadap Audit Delay. JOM Fekon, 4(1).

Tambunan, P. U. (2014). Pengaruh Opini Audit, Pergantian Auditor dan Ukuran Kantor Akuntan Publik terhadap Audit Report Lag (Studi Empiris Pada Perusahaan Manufaktur yang Terdaftar di Bursa Efek Indonesia ). Jurnal Akuntansi Universitas Negeri Padang, 3(1).

verawati andhika, ni made, \& Wirakusuma, made gede. (2016). Pengaruh Pergantian Auditor, Reputasi Kap, Opini Audit Dan Komite Audit Pada Audit Delay. Jurnal Akuntansi Universitas Udayana, ISSN: 2302-8556, 17(2), 2302-8556. https://doi.org/ISSN: 2302-8556

Wiryakriyana, A. A. gede, \& Widhiyani, S. (2017). Pengaruh Ukuran Perusahaan, Leverage, Auditor Switching, Dan Sistem Pengendalian Internal Pada Audit Delay. E-Jurnal Akuntansi Universitas Udayana 10.1, 19(1), 771-798. https://doi.org/ISSN : 2302-8556

Wulandari, I., \& Wiratmaja, I. D.N. (2017). Pengaruh Audit Tenure dan Ukuran Perusahan Klien Terhadap Audit Delay Dengan Financial Distress Sebagai Pemoderasi. E-Jurnal Akuntansi Univeristas Udayana, 21(1), 701-729. 